\title{
Liturgiese verdieping van die erediens op grond van kinders se deelname
}

\author{
Ben de Klerk \\ Skool vir Kerkwetenskappe \\ Potchefstroomse Universiteit vir $\mathrm{CHO}$ \\ POTCHEFSTROOM \\ E-pos: kwsbjdk@puknet.puk.ac.za
}

\begin{abstract}
Liturgical deepening of worship service as a result of children's participation

What kind of deepening can be brought about for the congregation by children participating in worship service? Liturgical deepening can be stimulated by adults implementing new ways by which children can contribute to worship service. The presence of children should have an effect on the content and structuring of the liturgy, in the same way as the presence of the elderly and other adults ought to have. Children participating in worship service can contribute to discover a fresh, childlike sincerity in spirituality. For this reason children should not to be entertained; to the contrary, the affective, emotional and rational aspects of the entire congregation's listening to the Word, appropriating it to themselves and responding to God, gain in depth by children's participation. Another aspect of the liturgy by which children's participation can heighten adults' sensitivity is non-verbal communication. Furthermore, the preacher accommodating children in addition to adults in his preaching, is compelled to take his congregation on an exploring trip by which the admiration and worship of God will be the final results.
\end{abstract}

\section{Opsomming}

Liturgiese verdieping van die erediens op grond van kinders se deelname

Watter verdieping kan die deelname van die kind in die erediens vir die gemeente meebring? Verdieping in die liturgie kan bevorder word as daar vernuwing in die denke van volwassenes kom oor die verryking wat kinderdeelname in die erediens kan bring. Die teenwoordigheid van kinders moet 'n uitwerking hê op die inhoud en vormgewing van die liturgie, net soos die teenwoordigheid van 
bejaardes en ander volwassenes dit behoort te doen. Kinders se deelname aan die erediens kan volwassenes help om 'n vars, kinderlik opregte spiritualiteit te ontdek. Daarom moet kinders nie vermaak word nie, maar deur hulle deelname word die affektiewe, emosionele en rasionele aspekte van die aanhoor en toeëien van die Woord en die respons van die hele gemeente teenoor God verdiep. Nog 'n aspek van die liturgie waarin die kind volwassenes se sensitiwiteit kan verskerp, is die nie-verbale kommunikasie in die diens. Verder word die prediker wat benewens die volwassene, ook die kind in sy prediking in berekening bring, gedwing om die gemeente saam op 'n ontdekkingsreis te neem waar bewondering vir en verering van God die eindresultaat is.

\section{Inleiding}

In die erediens kom 'n verskeidenheid mense saam: hulle verskil in ouderdom, in opleiding en sosiale agtergrond, in Bybelkennis en in kerklike betrokkenheid. En tog is hulle saam die huisgesin van God, één gemeente wat God se teenwoordigheid erken en vier (Zwaan, 1998: 388). In hierdie huisgesin is die een nie belangriker as die ander nie en nie een lid van die God se gesin mag in die erediens afgeskeep of eenkant geskuif word nie. Die vraag is egter of daar nie in die praktyk van gereformeerde eredienste 'n soort liturgiese apartheid (Holper, 1991: 86) ontstaan het deurdat kinders apart vir kinderdienste of vir 'n deel van die diens gehanteer word nie. Erger nog - dat kinders "apart gehou word" deurdat hulle in die erediens vergeet word: hulle teenwoordigheid maak geen verskil in die inkleding van die liturgie en die aanbieding van die prediking nie. Dit kan by kinders en jongmense lei tot verveling in die samekoms, met die moontlike gevolg dat hulle afsydig en vervreemd kan raak van die erediens (Barnard, 1988:352). Opnames wat in negentigerjare van die vorige eeu deur die Nederduitsch Hervormde Kerk van Afrika en die Gereformeerde kerke in Suid-Afrika gemaak is, dui aan dat 'n groot aantal kinders nie by die erediens betrokke is nie (vgl. Beukes, 1990:613; GKSA, 1990:454).

Wanneer die kind se situasie in die erediens en prediking as belangrik beskou word, beteken dit nie dat volwassenes nou na die kind moet oorbuig of toeskouers moet word van wat die kinders doen nie. Dit vra dat - soos by bejaardes en ander volwassenes - die plek van die kind in die verbondsgesin, ook in die samekoms van God se huisgesin, gerespekteer en ontwikkel moet word. Die kleinste kindjie moet soms opgetel word om te sien watter handelinge plaasvind of op die skoot getel word om te verduidelik wat God sê of teen die bors vasgedruk word om te laat voel wat die teenwoordigheid van God vir gelowiges beteken (Houtman, 1986:57). Die vraag wat eerlik beantwoord moet word, is dus: 
blyk dit duidelik dat kerke voldoende kinder- en jongmenssensitief is wanneer hulle God as verbondsgemeente in die erediens ontmoet? Die verbondskind verdien besondere aandag in die erediens op grond van die doop waarin én ouers én gemeente beloof om die onmondige kind deur onderrig en modellering voor te gaan. Die klein kindjie word in die erediens meegeneem in die gehoorsame ontvang van die Woord en die verheerliking van God in die feestelike byeenkoms, omdat daar vir die kind niks beter kan wees as om so by die gemeente van Christus ingesluit te wees nie (Zwaan, 1998:389).

In die navorsing oor die kind in die erediens is die afgelope tyd meestal gefokus op die bereiking van kinders in die prediking (Barnard, 1988: 351-372), die noodsaak om aan kinders 'n plek in die erediens te gee (Beukes, 1990:613-645; Victor, 1996:238-256) en op kinderkommunie (Clasen, 1989; Daunton-Fear, 1995:273-282; Holper, 1991:85-91; Van Wyk, 1996:305-316). Hierdie artikel wil vanuit 'n ander hoek die kind en jongmens se funksie in die liturgie probeer navors, naamlik watter verdieping die deelname van die kind in die erediens van die gemeente kan bring. Die oorkoepelende vraag is dus: kan die deelname van kinders die erediens verryk en indien wel, hoe kan dit gebeur? Hoe kan die kind prakties bydra daartoe dat die momente van die liturgie vir elke erediensdeelnemer nog groter verdieping in sy/haar gemeenskap met God meebring? In die artikel sal eers gefokus word op die feit dat die deelname van kinders die erediens kan verdiep, en dan op die "hoe" daarvan.

\section{Vertrekpunte vir die verdieping van die erediens deur die deelname van kinders}

\subsection{Die kind moet aan al die elemente van die erediens deelneem}

Die debat rondom sogenaamde kinderdienste het nog nie tot 'n einde gekom nie, want kerklike vergaderings handel daarmee en ernstige gesprekke word nog steeds daaroor op die internet gevoer (vgl. LePine, 2000 en Matto, 2001). In die praktyk word kinders in sekere gemeentes heeltemal apart van die normale erediens gehanteer, en in ander gevalle gaan hulle vóór die preek na 'n aparte lokaal en kom of na die preek terug, of glad nie (Barnard, 1988:353). Hierdie soort afsonderlike kinderdienste kan nie teruggevoer word tot die vroeë kerk waar kinders uitgestuur is voor die viering van die Nagmaal nie (die missa fidelium) en ook nie na die tyd van Calvyn waar die tweede diens in Genève 'n soort openbare katkisasiediens was nie. Dit kan eerder herlei word na die sogenaamde Sondagskool wat in 1830 in Nederland begin is (Houtman, 
1986:39). Die NG kerk het in 1986 duidelik standpunt ingeneem teen kinderdienste en die Gereformeerde Kerke het in 2000 'n beginselbesluit geneem: "Kerkrade moet toesien dat verbondskinders voortdurend sal groei in hulle deelnemende en ontvangende betrokkenheid tydens die hele erediens" (GKSA, 2000:443).

Die uitsluiting of ignorering van die kind kan die erediens negatief beïnvloed om die volgende redes:

- 'n Kind is altyd met verstand, hart, emosie, wil en liggaam in alles, ook in die erediens, betrokke. Die ignorering van die kind kan dus meebring dat eensydige klem op die kognitiewe verstaan van die preek gelê word.

- Tweedens verskeur hierdie uitsluiting van of onsensitiwiteit teenoor die kind die huisgesin en die gesin se gesamentlike ontmoeting met God. Daarmee kan die verbondenheid van gelowiges met hulle kinders in die diens verlore gaan.

- Derdens word die huisgesin van God verskeur, want die ontmoeting van God met sy volk sluit elke kind ook in (Thomas, 1992:10). Die kind is deel van die verbond en die erediens geskied op grond van die verbond en vernuwe die verbond en daarom spreek dit vanself dat die kind moet deelneem aan al die momente van die erediens (Victor, 1996:246).

Die mees kritieke jare vir die kind om sy geestelike wapenrusting te slyp is tussen 5-13 jaar en in die prediking word hierdie wapenrusting gebied en leer die kind dit gebruik, nie net intellektueel nie, maar deur in die midde van die kerk van die Here te wees (Matto, 2001). Dawn (1995: 118) stel dit so:

I did not know at the time (childwood) that all those experiences (in the worship service) were sinking in my bones - that I was learning the language of prayer and hymnody, of doctrine, scripture and liturgy. But I was. I was slowly but surely being taught the language and worldview of the christian faith which has nourished me all my life long.

Die teenwoordigheid van kinders in die erediens moet 'n konktrete uitwerking hê op die inhoud en vormgewing van die liturgie (waaronder die prediking) (Stosur, 2001). Die prediker wat die jong tiener as teikengroep vir sy prediking in gedagte hou, sal met eenvoudige taal, beelde en voorbeelde uit die lewe die hele gemeente dien. Die fokus op die kind is dus nie bloot om eredienste "kindervriendelik" te maak nie, maar veral om die belewing van die ontmoeting met God deur die deelname van verbondskinders te verdiep. 


\subsubsection{Die kind se deelname aan die Nagmaal}

Beteken deelname aan al die elemente van die erediens dat kinders ook van kleutertyd mag deelneem aan die Nagmaal? Debatte hieroor is die afgelope dertig jaar in die meeste Christelike kerke in die wêreld gevoer. Verskeie gereformeerde kerke in die buiteland en in Suid-Afrika laat kinders tot die Nagmaal toe op bepaalde voorwaardes. Onder dié voorwaardes is die verstaan waaroor dit in die Nagmaal gaan, persoonlike geloof in Jesus Christus as die kind se persoonlike verlosser en deeglike onderrig voor die viering deur veral die ouers (Clasen, 1989:6,7; Lane, 1992:13-15). Sommige van die kwessies wat nog bespreek word, is of die Nagmaal nie juis geloofsversterkend werk in die lewe van jongmense wat moet groei tot geloofsbelydenis nie; of 1 Korintiërs 11 beteken dat die kind intellektueel "die liggaam en bloed van die Here" moet kan onderskei as voorwaarde, en of daar nie 'n skeiding tussen die twee sakramente gemaak word deurdat die doop wel aan babas bedien kan word, maar dat die Nagmaal vir kindertjies "geslote" bly (vgl. Byars, 1997:257).

Van Wyk kom tereg tot onder andere die volgende konklusies: Nagmaalgangers moet in staat wees om hulleself te kan ondersoek en oor die onderskeidingsvermoë beskik om veral die Nagmaal van 'n gewone maaltyd te onderskei as viering van die dood en opstanding van Christus. Openbare belydenis moet tussen tien- en vyftienjarige leeftyd afgelê kan word deur kinders wat Christus en sy weldade kan omhels. Daarna moet verdere onderrig gegee word, verpligtend tot na die puberteitsjare en vrywillig selfs tot in gelowiges se ouderdom (vgl. Van Wyk, 1996:316, 317).

Die Nederlandse Geloofsbelydenis, artikel 35, stel dit dat die Nagmaal as sakrament ingestel is "om mense te voed en te onderhou wat Hy reeds wederbaar het en in sy liggaam, die kerk ingelyf het". Deur die wedergeboorte kry die gelowige nuwe lewe en dit is hierdie nuwe lewe wat in die Nagmaal deur gemeenskap met Christus gevoed word (vgl. De Klerk, 1990:168-170). Wanneer oorweeg word wie Nagmaal mag gebruik, is die vraag na die wedergeboorte dus van deurslaggewende belang. Die teken van die wedergeboorte is geloof in Christus as die Here. Indien 'n kind dit kan bely en die kern van die geloof toegeëien het, sou belydenis van geloof moontlik wees. Hierdie oordeel moet ook deur die gemeente (deur sy kerkraad) gedoen word en dan kan die kind belydenis van geloof aflê en aktief aan die Nagmaal deelneem. Die kind moet egter steeds verpligte voortgaande toerusting kry. Die kombinasie van onderrig en versterking deur die gebruik van die Nagmaal kan net dien tot geloofsgroei, veral in die moeilike puberteitsjare. Die kleiner kind wat nie die brood fisies eet en die wyn drink nie, maar die handelinge en 
toesegging daarvan sien en hoor, word nie daarmee van die handeling van die Nagmaal uitgesluit nie. In die kindjie se reaksie op die handelinge leer die gemeente om hierdie sakrament verwonderd, dankbaar en met blydskap te vier.

Die deelname van kinders behoort by al die elemente in die samekoms van die gemeente 'n nuwe visie op die handelinge te bring.

\subsection{Die kind se teenwoordigheid aksentueer bestaande liturgiese beginsels}

'n Belangrike uitgangspunt is dat dieselfde liturgiese beginsels wat vir volwassenes geld, ook vir kinders geld (Young, 1998:90). Drie van die beginsels word hier as voorbeelde geneem, naamlik: God neem die inisiatief in die ontmoeting, die erediens het 'n dinamiese aard en opregtheid by deelnemers is noodsaaklik.

\subsubsection{God neem die inisiatief in die ontmoeting}

Die erediens is ' $n$ drieërlei ontmoeting van God met sy gemeente, sy gemeente met Hom en die gemeente met mekaar. God neem die inisiatief en maak dit moontlik vir die gemeente om Hom en mekaar in Christus te ontmoet. Met "ontmoeting" word 'n lewende, dinamiese gemeenskap bedoel waarin God sy gawes aan die gemeente gee om Hom te kan dien en verheerlik. God ontmoet die gemeente as versamelde groep en dit sluit alle lidmate, belydende én dooplidmate, in. Die erediens het met die lewensiklus van elke deelnemer te doen en kinders en volwassenes beeld die volle lewensiklus van jeug tot ouderdom aan mekaar uit. Dit kan "biografies verankerde" eredienste genoem word (Kloppers, 1997:137). As voorbeeld hiervan betrek sommige kerke oud en jonk in die gemeente by die aflê van die doopsbelofte in die erediens:

Do you, as members of the church of Jesus Christ, promise to guide and nurture N. by word and deed, with love and prayer, encouraging them to know and follow Christ and to be faithful members of his church (Presbyterian Church of America; vgl. Caldwell, 1997:246).

Die kind se teenwoordigheid beklemtoon dat God die gemeente as korpus ontmoet en nie in die eerste plek as afsonderlike individue nie en dat die gemeente as geheel, in al sy dele, mekaar in Christus ontmoet.

\subsubsection{Die erediens het 'n dinamiese aard}

Die hart van die gemeente is die erediens waaruit energie, motivering en vreugde kom om God in die wêreld as mense van sy Koninkryk te dien. In die erediens word die dinamiek van God se Woord geaktiveer en kry 
die gemeente geleentheid om op die dinamiek van die Woord te reageer in aanbidding, lofprysing, geloofsbelydenis, verootmoediging en deelname en viering van die sakramente, die gebed, liefdegawes en diensbetoon in en buite die samekoms (Victor, 1996:241). In die erediens gebeur kragtige dinge: God praat en sy Woord is in staat om lewens te verander en sy Woord gee krag aan gelowiges om Hom, mekaar en die wêreld te dien. Klein en groot staan daarom verstom oor die wonder van die versterking van geloof deur die Heilige Gees. (Gordon, 1992:193). Kinders se deelname hieraan en hulle bewondering van God kan volwassenes help om 'n meer kinderlike en volledige spiritualiteit te ontdek (Batchelder, 1992:38).

Kinders se erediensbelewing benadruk dit aan volwassenes dat alle sintuie betrokke moet wees in die erediensgebeure, want selfs kleuters kan die teenwoordigheid van God aanvoel en bewonder wanneer hulle die gesigsuitdrukking, liggaamstaal en stem van hulle ouers waarneem (Fowlkes, 1992:608). Die bewondering wat 'n kind vir God uitstraal, werk weer aansteeklik in op die ander deelnemers aan die erediens. Kinderdeelname aan die liturgie bring dus energie en juis in hierdie verband het Young, (1998:93) in omvattende navorsing bevind dat die reaksie van volwassenes op die spontane betrokkenheid van kinders in die erediens uiters positief is.

\subsubsection{Opregtheid by deelnemers is noodsaaklik}

Kinders is dikwels goeie barometers vir wat eerlik en opreg en wat vals en oneg is. Die liturg wat hulle teenwoordigheid genoegsaam in ag neem, sal gedwing word om kinderlik en opreg te wees in die aanpak en begeleiding van al die liturgiese handelinge. Hy sal dit byvoorbeeld vermy om ter wille van kinders 'n soort vermaaklikheidskultuur in die erediens in te bou. Om die kind verkeerdelik te probeer vermaak met allerlei kunsgrepe, kan die erediens gedegradeer word tot 'n soort verbruikersitem wat kinders en volwassenes in die erediens tevrede probeer stel. As die liturgie net pret is, kan die krag wat uit die erediens voortspruit in tye van terminale siekte, onstabiliteit in die gesin of ander terugslae, gemis word. Die liturgie moet sterker kos (suiwer, konkrete en opregte Woordverkondiging en aanbidding), genesende medisyne (verootmoedigende skuldbelydenisse) en duiselingwekkende water (vrees en bewondering vir God se krag, liefde, oordeel en genade) voorsit aan oud en jonk (De Klerk, 2000:457). 'n Soort populêre (pop) liturgie is ingestel daarop om kinders (en volwassenes) te vermaak en dan kan die neiging bestaan om kinders daardeur in die erediens te degradeer tot toneelspelers en kunstenaars (Veith, 1998:31). Daar is immers 'n reuse verskil tussen die voed van die lammers van Christus se kudde en die blote vermaak van kinders (Mackenzie, 1988:100). 
Net so groot soos die gevaar van onegte formalisme vir kind en volwassene is, so gevaarlik is vormloosheid in die erediens. Die erediens is wel 'n fees, maar mag nie 'n vermaaklikheidsprogram met 'n klompie items word nie.

Die kriterium is nie hoe effektief die gemeente vermaak word met 'n verskeidenheid van interessanthede nie, maar hoe effektief die gemeente betrek is by die teologies-verantwoordbare liturgie (Müller, 1990:11)

\subsection{Die kind se teenwoordigheid help om atmosfeer in die erediens te skep}

Dingemans (1983:388) wys op die belang van veral die atmosfeer in die erediens. Bejaardes bring as voorbeelde van God se trou in die verlede 'n bepaalde atmosfeer in die erediens in. Gelowiges in die krag van hulle lewe skep die idée van stabiliteit wat inherent eie aan die gesin is. 'n Liturg wat voorgaan in 'n erediens wat gepak is met studente sal weet watter energie so 'n atmosfeer by hom/haar wakker maak. Net so bring kinders (babas, kleuters en skoolgaande kinders) 'n eie unieke atmosfeer in die erediens. Vir die kleiner kindjie is die atmosfeer (die erns, vrolikheid, blydskap, oorgawe, nederigheid, betrokkenheid) belangriker as die woorde en begrippe wat gebruik word. Die kleuter se nasê van enkele woorde in 'n gebed of die naboots van die handgebare van die prediker, of die saamsing van liedere met heeltemal ander woorde en 'n ander melodie as die lied wat die gemeente sing, kan die gemeente in verwondering bring voor God die Heilige Gees, wat kragtig in die kinderhart werk (Caldwell, 1997:250).

Volwassenes en kinders is kinders van God en moet in die teenwoordigheid van God soos kinders word. Volwassenes benodig die gawe van die kind met sy/haar verstommende reaksie op God se wonders, op die verhale in die Bybel en die feit dat gelowiges spontaan en kinderlik met die Heilige God kan kommunikeer en alles voor Hom kan blootlê. Die volwassene moet soos die kindertjies word en hy/sy het die modelle (kindertjies) in die erediens daarvoor nodig:

Children have an incredible ability to grasp images adults fail to see. We need such eyes. Seeing as children see, tasting as children tast, touching as children touch, with delight, can help us grow into the way of life of the Spirit. We engage children in worship not because we should do so for their sake, but because we must do so for the sake of the whole Body of Christ to which they belong (Wilkey, 1997:268). 
Kinders kan volwassenes lei tot verdieping van hulle verstandelike en emosionele belewing van blydskap en pyn, hartseer en dankbaarheid in die teenwoordigheid van God. Die kleuter wat die een oomblik droewig huil en kort daarna uitbundig lag en dankbaar is wanneer hy/sy deur 'n ouer getroos word, is immers imbool van die vertroostende werk wat die Heilige Gees regstreeks in die hart van die erediensdeelnemer doen (Love, 1997:259-262).

Die sien en ervaar van die kind in die erediens behoort die volwassene in aanraking te bring met die kerk deur die eeue. Die kinderstem in die samekoms moet nie as steurend ervaar word nie, maar as simbool van die verbond van geslag tot geslag (Brugh, 1993:74-76). Kinders skep 'n bepaalde atmosfeer in die erediens, want die kind se verbeelding, wat God op daardie stadium van sy/haar lewe so ryklik aan hom/haar gegee het, sal die verharding en vormgodsdiens wat moontlik mag inkruip in elke erediensdeelnemer se binnekant, teëwerk (Holeton, 2000:111).

Die duidelike gevolgtrekking uit die vertrekpunte hierbo genoem, is dus dat die kind met sy/haar aktiewe deelname aan die erediens verdieping in die samekoms van God en sy volk kan bring.

\section{Die praktiese betrokkenheid van die kind in die verdieping van die erediens}

Die vraag wat nou beantwoord moet word, is hoe die kind prakties daartoe kan bydra dat die momente van die liturgie vir elke erediensdeelnemer nog groter verdieping in sy/haar gemeenskap met God meebring?

\subsection{Enkele voorvereistes vir die kind se praktiese betrokkenheid}

Die huidige inkleding van gereformeerde eredienste hou nie genoegsaam rekening met die kind se deelname daaraan nie en ook nie met sy/haar fisiese, emosionele en godsdienstige ontwikkeling nie. Die affektiewe en emosionele word dikwels ten gunste van die rasionele onderbeklemtoon, nie net tot nadeel van die kind nie, maar van die hele gemeente. Die norm vir geskiktheid van deelname aan die erediens word gesoek rondom die preek en die verstaanbaarheid van die preek vir die volwassene en die kind (Victor, 1996:238). Wanneer die aanwesigheid van die kind weinig verskil maak in die hantering van die liturgie, moet die kind noodwendig 'n passiewe toeskouer word. Die preek kan dan maklik in die taal en begripsvermoë van die verstandelik gevorderde volwassene gelewer word en mag daarom nie die lewe en probleme wat by kind sowel as volwassene voorkom, aansny nie. Waar die lewewekkende prediking by kind en volwassene verbygaan, verloor die 
erediens én die God wat vereer word, dikwels die bewondering van die kind (Barnard, 1988:352). Daar moet dus 'n groter gevoeligheid kom by die liturg en kerkraad ten opsigte van die waarde wat die kind se deelname aan die erediens vir die gemeente kan meebring.

Verder behoort kinders deur mondelinge onderrig, sowel as deur blootstelling aan die liturgiese gebeure geleer word wat dit vir die gemeente beteken om as gemeenskap van gelowiges saam te kom. Hulle moet leer waarom en hoe handelinge verrig word sodat hulle die dieper betekenis van simbole en rituele, die waarde van stilte, die belangrikheid om God te hoor en te antwoord, kan ervaar. So kan hulle ontdek wat dit beteken om God se volk te wees en hoe belangrik dit is om anders as die sondige wêreld te lewe (Dawn, 1995:118). Die kognitiewe aanspraak, verklaring en die leer om te verstaan is nie die belangrikste nie, maar wel die sosialisering (vgl. Kloppers, 1997:135), met ander woorde die meemaak, die nabootsing, die eenvoudige daarby-wees en die altyd weer daarby-wees. Liturgie kan immers nie uit 'n boek geleer word nie, liturgie kan slegs ervaar word in 'n gemeenskap van verskillende ouderdomsgroepe en veral om die handelinge deur die oë van 'n kind te sien.

\subsection{Die praktiese betrokkenheid van die kind in die erediens in die algemeen}

\subsection{1 'n Strategiese beplanning wat die kind betrek}

Voordat op die besondere momente van die erediens ingegaan word, word enkele algemene aspekte in die beplanning van die erediens ondersoek. Die erediens moet in sy totaliteit beplan word om die doel te verwesenlik om kinders so in ag te neem dat hulle die diens kan verryk. Dit vra 'n besondere aanpak wat Beukes (1990:641) "'n geheel strategie beplanning" noem. Dit beteken dat met kinders in hulle verskillende ontwikkelingsfases rekening gehou moet word. Teoloë, opvoedkundiges en kommunikasiekundiges sal deurlopend saam moet besin hoe om kinders en volwassenes gelyktydig in die erediens te betrek. Elke deelnemer se totale wils-, emosionele en verstandelike lewe sal ingeskakel moet word. Konkreetheid is vir kinders noodsaaklik en volwassenes sal daarby baat as van abstrakte begrippe en terme na konkrete voorbeelde uit die daaglikse lewe beweeg word. Die denkwêreld van die kind sal moet oopgaan voor die liturg deurdat hy/sy naby aan elke kind moet leef en ook moet luister na die verbeeldingspeletjies van die kleuter. Die liturg sal self kind moet bly in sy voorbereiding deur pastoraal teenoor kinders ingestel te wees, kindergroepe gereeld te besoek en hulle persoonlik te leer ken. 
Die liturgiese kommissie wat saam met die liturg eredienste beplan, moet een of twee kinders uit verskillende ouderdomsgroepe insluit sodat rekening gehou kan word met kinders se verskillende behoeftes (Batchelder, 1992:33). Dit moet weerklank kry in ten minste een lied wat gesing word en in die gebede van die liturg of ander gebedsvoorgangers. In die gemeenteblad moet die kleiner kind met beelde gelei word om die dinamiese voortgang van die liturgie te kan volg (Haystead, 1991:188, 189).

\subsubsection{Gebruik die kind se spontane vriendelikheid}

Die kind se spontane vriendelikheid kan 'n groot aanwins vir erediensdeelnemers wees. Die aankoms van erediensdeelnemers by die plek waar die samekoms plaasvind, is belangrik - nie alleen vir nuwe deelnemers aan die erediens nie, maar ook vir die gemeente. Wie groet die gemeentelede? Is dit die gryskoppe wat die groetwerk doen en so 'n eensydige beeld van die gemeente uitstraal. Of word daar ruimte geskep vir jongmense en kinders om die gemeentelede te groet en mense sodoende iets van die vitaliteit van die bruid van Christus te laat ervaar? Mackenzie (1988:97) sê tereg: "What is the body language of the body of Christ? What signs, symbols, or gestures convey the sense of welcome, care, affection, world interest, service?"

Omdat die erediens 'n verbondskant het en daarom 'n gesinsaangeleentheid is, is dit nie bloot 'n samekoms om 'n toespraak aan te hoor nie, maar 'n fees van gesinne binne die gesin van God waarin die gesinslede dinge aanleer deur daar te wees en mee te doen. Die vriendelike verwelkoming deur gesinne, wat kinders en ouer mense insluit, praat die taal van die totale liggaam van Christus.

Die kindervriendelike erediens is dus ' $n$ samekoms waarin vir kinders ruimte geskep word om hulle spontane vriendelikheid aan ander oor te dra (Kloppers, 1997:135). Haystead (1991:182) wys daarop dat volwassenes nie altyd goeie modelle is van vriendelikheid vir en teenoor kinders nie. 'n Ander wyse waarop die spontane vriendelikheid van die kind tot uitdrukking kan kom, is deur voor die aanvang van die diens die tekenprente van kinders (van hulle belewenis van erediensgebeure) in die voorportaal te plaas. So kan iets van die blydskap van die gemeente om saam te kom deur kinders verbeeld word. Vriendelikheid word uitgestraal deur die kind in die verskillende momente van die diens regstreeks te betrek, maar dit alleen is nie genoeg nie. Vriendelikheid deur die taalgebruik in die gebed, prediking en die taal van die lied is hierin van die grootste belang. Dit beteken nie dat slordige taal gebruik moet word nie, die soort taal wat die kind teenoor sy maats gebruik nie, maar eenvoudige treffende taal vol beelde en metafore wat uit die kind 
en volwassene se leefwêreld geneem is. Die begrip orde en ordelik van 1 Korintiërs 14:33 dui immers aan dat alles normaal, fatsoenlik, netjies, maar ook eietyds moet wees (De Klerk, 1987:74). Die kind in die erediens dwing die liturg en prediker om te konsentreer op die eietydse in die taal en in die liturgiese handelinge.

\subsubsection{Simbole waarmee kinders die samekoms kan verryk}

Die kind kan die erediens verder verryk deurdat spesifieke simboliese take by geleenthede aan kinders gegee word. Voorbeelde hiervan is die inbring van die Bybel net voor die aanvang van die diens en die oorhandiging daarvan aan die liturg of voorleser. Verder die inbring van die doopwater vir die doop van kindertjies of die inbring van die brood en wyn deur kinders van verskillende ouderdomsgroepe.

Kinders en volwassenes word verryk deur die visuele en veral die kind se waardering en sensitiwiteit vir die visuele, simbole, seremonies en die rituele (vgl. Vos \& Pieterse, 1997:118-126) moet gestimuleer word. Die simbole in die kerkgebou, soos die Bybel se sentrale plek, die simbool van die doopvont en van die beker en die bord van die Nagmaal is visuele kuns wat die kind dikwels geestelik veel dieper raak as die volwassene wat daarvoor afgestomp raak (Nelson, 1995:79). Die kind se aansteeklike bewondering tydens seremonies wat met die huweliksluiting, gebeure rondom die graf en die aflegging van geloofsbelydenis te doen het, kan nie onderskat word nie. Hierin speel die kerklike jaar ook 'n belangrike rol. Die kerklike jaar bied aan huisgesinne en gemeentes die geleentheid om die feeste op verskillende en aanskoulike wyses te vier. Daar is liedere eie aan die Paasfees, Pinksterfees en Kersfees. Kinderdeelname verryk die feestelikheid omdat hulle sonder pretensie kan feesvier (Halmo, 1996:189; Vandercook, 1992:24).

Nog 'n aspek van die erediens waarin die kind volwassenes se sensitiwiteit kan verskerp, is die nie-verbale kommunikasie in die diens. Daar is baie meer nie-verbale kommunikasie in die erediens as wat normaalweg gedink word: die gebare van die oë uit eerbied in gebed toemaak, die hande vou en die uitgestrekte hande by die uitspreek van die seën; die bewegings van sit, staan of kniel by byvoorbeeld die huwelikdiens, die beweging van die voorganger van die preekstoel na die tafel en van die gemeente wat na die tafel beweeg, die prosessie van die binnekom van die prediker, gevolg deur ouderlinge en diakens en die inbring van die kindjie om gedoop te word. Al hierdie bewegings druk iets uit van die gevoelens en emosies wat by verskillende liturgiese handelinge hoort (Zwaan, 1998:392). 


\subsection{Die praktiese betrokkenheid van die kind in die verskillende momente van die erediens}

Daar is ten minste vier belangrike momente in die samekoms van die gemeente: die gemeente tree ordelik en op 'n bepaalde manier toe om God te ontmoet (die ontmoetingsdiens), daarna verootmoedig hulle hulle en bely skuld, waarby die vergewing en absolusie hoort (die verootmoedigings- en versoeningsdiens). Ook bid die gemeente om die verligting van die Gees (epiklese), luister hulle na die Skriflesing en prediking, vier die sakramente (die Woorddiens) en antwoord op die ontmoeting, die Woord en prediking in dankgebed, smeking en voorbidding (die antwoorddiens). Die verryking van hierdie momente deur die teenwoordigheid van die kind, word nou bespreek.

\subsubsection{Die kind en die introïtus en die verootmoedigings- en versoeningdiens}

Die introïtus as intog bevat die erkenning dat God in die samekoms van die gemeente teenwoordig is (votum) en sy volk in staat stel (met die groetseën) om Hom te ontmoet. Die reaksie van die gemeente op die intrede van God deur lofprysing in lied en belydenis in woord en lied vorm deel van die introïtus. Die kind kan die liturgiese belewing van die introïtus verryk deurdat kinders in wisselsang byvoorbeeld die eerste deel van Psalm124:4; 121:1 en 43:3 kan sing en die hele gemeente die tweede deel van die betrokke liedere. So sou dit ook by die die sing van die lofliedere en die belydenis kon gebeur. Die kinderstem bind hiermee die gemeente aan die geslagte wat gekom het en die geslagte wat nog kan kom.

Die gemeente wat in nederigheid toetree in die heilige teenwoordigheid van God erken die grootheid van God en sy eie nietigheid, kleinheid en geringheid voor God (vgl. De Klerk, 1999a:27-30). Hiervan is die kind 'n lewende simbool wat as model dien van die genade wat God aan die kinderlike gelowige gee. Christus se woorde dat gelowiges wat nie nederig soos die kindjie is nie, nie die Koninkryk sal binnegaan nie, is hier ter sake. In die gebed van skuldbelydenis kan ook tipiese sondes van kinders bely word en dit mag die uitwerking hê dat die gemeente se sondebesef, berou en gebed om vergewing verdiep word. Wilkey (1997: 263) beskryf die aangrypende voorbeeld van 'n Down Sindroom-kind se reaksie op die vryspraak nadat die liturg die skuld van die gemeente wat dikwels onderling twis, bely het. Hierdie kind het pas voor die diens met haar suster konflik gehad. $\mathrm{Na}$ die vryspraak het hierdie verstandelik gestremde kindjie spontaan hardop ten aanhoor van die hele gemeente uitgeroep: "Thank you Lord!" Die kind kan volwassenes dus begelei om 
affektiewe, nie-kognitiewe belewenisse van die skuldbelydenis en vryspraak te ervaar.

\subsubsection{Die kind en die Woorddiens}

Die Woorddiens in die vroeë kerk is tussen twee of drie persone verdeel, en wat met sekerheid vasgestel is, is dat dié wat uit die Skrif voorgelees het (selfstandige Skriflesing en Skriflesing waaruit prediking voortvloei) en dié wat die Skrif verklaar en toegepas het (die predikers), nie dieselfde persoon was nie (Deddens, 1981:43). Jonker (s.j.:116) pleit daarvoor dat die kind, wat die gawe daarvoor ontvang het, soms van hierdie Skriflesings waarneem, want daardeur hoor die gemeente die Skrif uit die mond van die kind op 'n nuwe, vars manier. Die voorwaarde is dat die liturg die week vooraf die betrokke kind moet begelei in die voorbereiding. Die belangrikste voorvereiste vir sowel voorleser as hoorders is dat hulle met die Heilige Gees vervul moet wees.

Die teenwoordigheid van die kind verskerp die prediker se aandag om verbondsmatig te preek en verbondsprediking bou die hele gemeente. Deur sensitief vir kinders onder die prediking te wees, word die prediker gedwing om die hele gemeente saam met hom op 'n ontdekkingstog te neem waar almal al meer van God in hulle lewe raaksien (Van't Zand, 1994:486). Die kind wat nie alles verstaan wat gepreek word nie, is vir die gemeente 'n waarskuwing dat geloof nie net verstaan impliseer nie, maar ook vertrou en toeëien. In die prediking moet die prediker God aan die gemeente uitwys en dit sluit in die bewuswording van die teenwoordigheid, genade en liefde van God (Beukes, 1990:631). Belangriker as om kinders afsonderlik in die prediking aan te spreek, is om in eenvoudige taal te praat, kort te preek en met 'n gemoedelike stemtoon te preek (Houtman, 1986:55; vgl. Barnard, 1988:367). Kinderpreke wat bloot moraliserende lessies aan die kind leer, verskraal die grootsheid van die evangelie, en hierdie wonder mag nie van kinders weggehou word nie. Die narratiewe genre in die Skrif kan beeldryk aan oud en jonk ' $n$ helder beeld van God se werk in sy wêreld gee. Beelde en metafore uit die kindertyd is vir die hele gemeente sprekend en daarom moet die prediker vertroud wees met kinders se leefwêreld. So sal hy ook die volwasse wêreld uit 'n ander hoek sien. Die visuele is vir die moderne mens met sy ingesteldheid op die oudio-visuele van groot belang en daarom kan die kinders die beeld wat hulle van die prediking gevorm het, na die diens teken en die volgende Sondag in die ingang van die kerkgebou uitstal.

In die sestiende-eeuse Reformasie het die praktyk ontwikkel wat die gawe van die profesie genoem word. Na aanleiding van 1 Korintiërs 14 beteken dit dat lidmate geleentheid in of na die erediens gegee moet 
word om God se Woord konkreet in verskillende lewensituasies toe te pas (De Klerk, 1987:229). Kinders moet hieraan deelneem en so die gawe van die profesie beoefen. Een van die kinders kan vooraf toeligting oor die prediking kry en dan in 'n kort woord die prediking konkreet toepas in die kind se lewensituasie. Dit sal die gemeente in verwondering voor God laat staan wanneer hulle hoor watter wysheid die Heilige Gees op so 'n jong leeftyd in die kind se hart geplaas het.

Die sakramente is sigbare tekens en al sou die kleiner kind nie aan die Nagmaal op dieselfde wyse as die belydende lidmaat kan deelneem nie, is die entoesiasme van die kind by die sien van die brood en wyn genoegsaam. Die blydskap wat uit kindergesiggies by die doop van 'n kindjie straal, is 'n konkrete boodskap van die blydskap wat God se beloftes aan elke gemeentelid bring.

\subsubsection{Die kind en die antwoorddiens}

God se Woord roep altyd 'n antwoord, 'n respons op. Die antwoord geskied deur gebed (gesing of gepraat), die gee van liefdegawes en sang (GKSA, 1997:759). Wanneer die kinders in die samekoms in aanmerking geneem word, sal die woord en die melodie van die liedere eietyds en vars bly. Die eietydse beteken nie populêre, sentimentele liedere nie, maar liedere met 'n kragtige inhoud, in eietydse taal, met singbare melodieë van goeie kwaliteit. Die kind wat sitting op die liturgiese kommissie of diensgroep het, sal ten opsigte van die inhoud van gebede belangrike insette kan lewer, want die kinderlike eenvoud is 'n wapen teen niksseggende clichés in die gebede. Die kind se belangstelling en ywer om die houer waarin die liefdegawe geplaas word, te hanteer en om te sien wat daarin is, behoort die gemeente met nuwe oë te laat kyk na hierdie besondere manier van dankie-sê en om daadwerklik iets te doen aan die nood van mense.

\section{4. 'n Voorbeeld van 'n erediens wat deur kinderdeelname verryk kan word}

Hierdie voorbeeld is in 'n sekere sin oordrewe omdat die betrokkenheid van kinders nie in elke erediens so oorweldigend sal wees nie en omdat daar groot variasiemoontlikhede is. Die kind sal byvoorbeeld nie by elke diens die Bybel inbring nie en ook nie altyd aan wisselsang deelneem nie. In hierdie een voorbeeld word heelwat meer moontlikhede gegee as wat in een erediens gebruik kan word:

By die aankoms van lidmate kan twee of meer huisgesinne (met kinders) die lidmate groet en verwelkom en aan hulle die inligtingsbrief van die gemeente gee. In die portaal van die kerk kan 'n uitstalling wees van 
kleuters en junior laerskoolkinders se sketse van gebeure in die erediens of beelde wat in vorige preke gebruik is. ' $n$ Kind kan die Bybel indra nadat die liturg plek ingeneem het en dit aan die liturg of voorleser oorhandig. Die kinders en jongmense van die gemeente kan in wisselsang met die gemeente die votum uit óf Psalm 43:3 óf Psalm $121: 1$ sing. Een van die kinders kon as lid van die liturgiese diensgroep vooraf gehelp het om lofliedere of liedere van skuldbelydenis, ensovoorts, uit te soek. 'n Hoërskoolkind kan die wetslesing waarneem en 'n jong belydende lidmaat by 'n ander geleentheid die selfstandige Skriflesing. Aan een of meer kinders kan die geleentheid gegee word om die gawe van profesie te beoefen in of na die diens deur die prediking konkreet toe te pas in die kind se lewensituasie. Insette kon ook vooraf gelewer word vir die voorganger in die gebed(e) ten opsigte van lofprysing, skuldbelydenis, dankie-sê en smeking en voorbidding vanuit die hoek van kinders. Kinders kan by geleentheid betrokke wees by die insameling van die liefdegawe. Kleuters sou ook 'n prominente plek by die doop van kindertjie kon kry en dalk een vers van 'n bekende lied saam met al die kinders en jongmense van die gemeente by die doopgeleentheid sing. Kinders kan na die diens dienswerk doen deur te help met tee en koffie wat aan gemeentelede bedien word.

\section{Samevatting}

Verdieping in die liturgie kan bevorder word as daar vernuwing in die denke van volwassenes kom oor die verryking wat kinderdeelname in die erediens bring. Die kind is ' $n$ integrale deel van elke moment in die erediens. Die teenwoordigheid van die kind moet 'n uitwerking hê op die inhoud en vormgewing van die liturgie, net soos die teenwoordigheid van bejaardes en ander volwassenes dit behoort te doen. Kinders se deelname aan die erediens kan volwassenes help om 'n vars, kinderlik opregte spiritualiteit te ontdek. Daarom moet kinders nie vermaak word nie, maar deur hulle deelname word die affektiewe, emosionele en rasionele aspekte van die aanhoor en toeëien van die Woord en die respons van die hele gemeente teenoor God verdiep. Kinders kan volwassenes lei tot verdieping van hulle belewing van blydskap en pyn, hartseer en dankbaarheid in die teenwoordigheid van God. Die kindervriendelike erediens is ' $n$ erediens waarin vir kinders ruimte geskep word om hulle spontane vriendelikheid aan ander oor te dra. Verder word die prediker wat benewens die volwassene, ook die kind in sy prediking in berekening bring, gedwing om die gemeente saam op 'n ontdekkingsreis te neem waar bewondering vir en verering van God die eindresultaat is. Verdieping in die erediens beteken dat die Gees 'n dieper besef van die heilige teenwoordigheid van God in die samekoms bewerk en daarmee gepaardgaande "aanbidding deur die Gees en in waarheid" (De Klerk, 
1999:316). Daar bestaan geen twyfel nie dat die teenwoordigheid van die kind in die erediens dien tot verdieping van die belewing van God se genade en liefde en ook bydra tot 'n verdere inspirasie om God met blydskap te antwoord en mekaar in liefde raak te sien.

\section{Bibliografie}

BARNARD, A. 1988: Erediens en prediking met die oog op die bereiking van kinders. Nederduitse Gereformeerde Teologiese Tydskrif, 29(4):351-372.

BATCHELDER, D.B. 1992. Worship rated G: Two case studies of opening the sanctury to children. Reformed Liturgy and Music, 26(1):32-39.

BEUKES, M.J. du P. 1990. Kinders in die erediens. Hervormde Teologiese Studies, 46(4):613-645.

BRUGH, L. 1993. Children's choirs as proclaimers. Liturgy, 11(1):74-76.

BYARS, R.P. 1997. Formation of children through sacraments. Reformed Liturgy and Music, 31(4):255-258.

CALDWELL, E.F. 1997. Parent's baptismal vows: Water, words and wonder. Reformed Liturgy and Music, 31(4):246-250.

CLASEN, F.J. 1989. Die kinderkommunie. 'n Prakties-teologiese studie. Pretoria : Universiteit van Pretoria. (D.D. Proefskrif.)

DAUNTON-FEAR, A. 1995. Resisting the tide. Christian initiation and communion reconsidered. Theology, 98(784):273-282.

DAWN, M.J. 1995. Reaching out without dumbing down. A theology of worship for the turn-of-the-century culture. Grand Rapids : Eerdmans.

DEDDENS, K. 1981. Waar alles van Hem spreekt. Groningen : Niemeyer.

DE KLERK, B.J. 1987. Die Heilige Gees en die verhouding Skriflesing, prediking en gebed in die erediens. Potchefstroom : PU vir CHO. (Th.D.-proefskrif.)

DE KLERK, B.J. 1990. Die persoonlike geloofsdaad van die Nagmaalsgebruiker. Koers, 55(1):163-178.

DE KLERK, B.J. 1999a. Skuldbelydenis en versoening as kommunikatiewe handelinge in die liturgie van die samekoms van die lewe. Praktiese Teologie in SuidAfrika, 14(1):23-45.

DE KLERK, B.J. 1999b. Vaartversnelling vra verdieping in die liturgie. In die Skriflig, 33(3):311-330.

DE KLERK, B.J. 2000. Liturgiese identiteitsvorming as antwoord op die invloed van die verbruikerskultuur. In die Skriflig, 34(4):451-468.

DINGEMANS, G.D.J. 1983. Aansluiten bij de ervaringswereld van kinderen. Praktische Theologie, 4:377-392.

FOWLKES, M.A. 1992. The developing child and worship. Reformed Liturgy and Music, 26(1):6-8.

GEREFORMEERDE KERKE IN SUID-AFRIKA. 1990. Handelinge van die vier-enveertigste nasionale sinode te Potchefstroom op 6 Januarie en volgende dae. Potchefstroom.

GEREFORMEERDE KERKE IN SUID-AFRIKA. 1997. Handelinge van die ses-enveertigste nasionale sinode te Potchefstroom op 6 Januarie en volgende dae. Potchefstroom.

GEREFORMEERDE KERKE IN SUID-AFRIKA. 2000. Handelinge van die sewe-enveertigste nasionale sinode te Potchefstroom op 8 Januarie en volgende dae. Potchefstroom.

GKSA

kyk GEREFORMEERDE KERKE IN SUID-AFRIKA 
GORDON, E. 1992. The relevance of the liturgy. Reformed Liturgy and Music, 26(4):189-194.

HALMO, J. 1996. Celebrating the liturgical year with children. Liturgical Ministry, $5(4): 187-194$.

HAYSTEAD, W. 1991. Worship with the whole church. (In Roehlkepartain, J.L., ed. Children's ministry that works! Basics \& beyond. Colorado : Group Books. p. 181-189.)

HOLETON, D.R. 2000. Welcome children, welcome me. Anglican Theological Review, 82(1):93-111.

HOLPER, J.F. 1991. Places at the table: New directions in Presbyterian worship. Reformed Liturgy and Music, 25(2):85-91.

HOUTMAN, R.A. 1986. Zo nemen wij de kinderen mee. Barneveld : De Vuurbaak.

JONKER, H. s.j. Liturgische oriëntatie. Wageningen : Zomer \& Keunings.

KLOPPERS, E.C. 1997. Liturgiese musiek as kommunikatiewe handeling in 'n postmoderne era. Pretoria : Universiteit van Suid Afrika. (D.Th.-proefskrif.)

LANE, W.B. 1992. Children and the sacraments: Baptism and the Lord's Supper. Reformed Liturgy and Music, 26(1):13-15.

LEPINE, P. 2000. Order of service - dismissing children during worship. [Internet:] http://www.fni.com/worship/2000. [Datum van gebruik: September 2001.]

LOVE, J.F. 1997. Liturgical foundation in an illiterate age. Reformed Liturgy and Music, 31(4):259-262.

MACKENZIE, J.A.R. 1988. Is there a family room in the house of God? Reformed Liturgy and Music, 22(2):97-100.

MATTO, K. 2001. The dangers of children's church. [Internet:] http://www.scionofzion.com/childchurch.htm. [Datum van gebruik: September 2001.]

MÜLLER, J. 1990. Die erediens as fees. Halfway House : NG Kerkboekhandel.

NELSON, R.A. 1995. Children at worship: the church of today. Word and World, 15(1):76-82.

STOSUR, D.A. 2001. "Children go"? Children's liturgy of the Word and the Sunday assembly. [Internet:] http://www.blessedsacrament.com/theology/stosur1.html. [Datum van gebruik: September 2001.]

THOMAS, V.C. 1992. Worship that welcomes children. Reformed Liturgy and Music, 26(1):9-12.

VAN'T ZAND, J.D. 1994. Die integrering van die verbondsjeug in die erediens deur middel van die prediking. In die Skriflig, 28(3):479-490).

VAN WYK, J.H. 1996. Kinderkommunie in diskussie. In die Skriflig, 30(3):305-319.

VANDERCOOK, L.D. 1992. Children and the liturgical year: reflections on practical application. Reformed Liturgy and Music, 26(1):23-25.

VEITH, G.E. 1998. Religion, culture and our worship. Concordia Theological Quarterly, 62(1):25-38.

VICTOR, K. 1996. Nogeens! Die kind se plek is in die erediens. Nederduitse Gereformeerde Teologiese Tydskrif, 37(2):238-256.

VOS, C.J.A. \& PIETERSE, H.J.C. 1997. Hoe lieflik is u woning. Pretoria : Raad vir Geesteswetenskaplike navorsing.

WILKEY, G.V. 1997. What children bring: a little child shall lead them. Reformed Liturgy and Music, 34(4):263-269.

YOUNG, T.L. 1998. Children, liturgies and catechesis. Liturgical Ministry, 7(2):89-95.

ZWAAN, S.P. 1998. Kind en liturgie. (In Oskamp, P. \& Schuman, N., reds. De weg van de liturgie. Tradities, achtergronden, praktijk. Zoetemeer : Meinema. p. 388394.) 


\section{Kernbegrippe:}

erediens

kinderdeelname

liturgiese verdieping

\section{Key concepts:}

children; participation of liturgical deepening worship service 